\title{
Kendali Model Kursi Roda dengan Electromyograf dan Accelerometer Menggunakan Metode Jaringan Saraf Tiruan
}

\author{
M. Adib Nursasongko," Ilham Ari Elbaith Zaeni, Anik Nur Handayani
}

Departemen Teknik Elektro, Universitas Negeri Malang, Karangbesuki Malang, Indonesia

*adibnursasongko@gmail.com

Kata Kunci :

Kursi Roda

Jaringan Saraf Tiruan

Electromyograf

Accelerometer

Arduino Uno

\section{ABSTRAK}

Kursi roda digunakan sebagai alat bantu untuk berpindah tempat bagi orang yang memiliki disabilitas pada bagian kaki. Namun, kursi roda konvensional biasanya dijalankan dengan mendorong kursi roda tersebut atau pengguna mengendalikan sendiri roda dari kursi roda yang dikendarainya. Namun untuk pengguna yang juga memiliki disabilitas pada tangannya tidak dapat mengendalikan sendiri kursi roda konvensional. Sebuah robot kursi roda dirancang untuk memudahkan para pengguna yang memiliki disabilitas khusus pada kaki dan tangannya. Robot ini dirancang untuk dapat dijalankan dengan menggerakkan otot pada dahi dan dengan cara memiringkan kepala. Jaringan saraf tiruan digunakan untuk memprediksi nilai sensor selanjutnya dan membandingkan dengan data nilai sensor sebelumnya untuk menentukan adanya kontraksi pada otot. Robot kursi roda ini dibuat dengan tiga bagian utama yaitu masukan dengan menggunakan sensor EMG (Electromyograf) dan sensor Accelerometer, sistem pengendali berbasis Arduino UNO dan sistem aktuator dengan menggunakan motor DC. Electromyograf (EMG) merupakan peralatan yang digunakan untuk menangkap aktivitas otot manusia yang pada penelitian ini sensor EMG dipasang pada dahi. Accelerometer yang nantinya akan dipasang pada bagian kepala mempunyai fungsi untuk mengukur percepatan akibat gravitasi bumi sehingga dapat digunakan untuk menentukan arah yang akan dituju. Pada penelitian ini hasil yang didapatkan adalah model mampu mendeteksi kontraksi otot dan dapat menentukan arah kursi roda sesuai yang diinginkan.

Wheelchair is used to help and transport person or patient which has difficulties to walk using their legs. In order to move, wheelchair needs someone's help to push from behind or a person sitting in a wheelchair should move the chair using their arm. However, for the disabled person especially arm and hand disabilities, cannot move the wheelchair. In order to move the chair there is a method using 
robot wheelchair, to help the disabilities using sensor and artificial neural network. Sensors used on these devices are EMG (Electromyography) and Accelerometer sensor. Data from sensors will be deliver to microcontroller based on Arduino Uno microcontroller, and will activate actuators to move the motors. An EMG sensor is placed on the forehead to detect the human muscular bioelectric signal, and the Accelerometer sensor is placed above the head to measures the acceleration due to Earth's gravity so that it can be used to determine the direction of the wheelchair movement. The result of this research is a model that able to detect the muscular contraction and it can determine the direction of the wheelchair as desired.

\section{Pendahuluan}

Kursi roda adalah kursi dengan roda kecil di depan dan dua roda besar di samping. Kursi roda umumnya digunakan sebagai alat bantu untuk berpindah tempat atau membutuhkan mobilitas bagi orang yang tidak bisa berjalan atau memiliki disabilitas pada kaki agar dapat melakukan aktivitas sehari-hari [1]. Seseorang yang mengalami kelumpuhan pada bagian kaki dapat menggunakan kursi roda sebagai alat penunjang mobilitasnya. Hingga saat ini banyak sekali penelitian tentang kursi roda yang menggunakan joystick sebagai pengendalinya. Namun pengunaan joystick masih sulit untuk dilakukan bagi pasien yang sudah lanjut usia dan pasien yang menderita quadriplegia[2]. Pada penelitian Jeffry Glen Sitanaya (2018) menggunakan dua sensor EMG yang dipasang masing-masing pada tangan kanan dan kiri. Pada penelitian ini digunakan mikrokontroller STM32F4 Discovery sebagai pemroses sinyal input dari rangkaian instrumentsi EMG, melakukan pengiriman data secara serial ke laptop dan menghasilkan sinyal PW yang diteruskan ke motor[2].

Electromyography adalah pemeriksaan elektrodiagnosis untuk memeriksa saraf perifer dan otot. Prinsip kerjanya adalah merekam gelombang potensial yang ditimbulkan baik oleh otot maupun saraf[3]. Otot merupakan bagian yang penting bagi tubuh manusia. Otot merupakan sebuah jaringan yang sangat penting pada tubuh manusia yang fungsinya sebagai alat gerak aktif untuk menggerakkan tulang. Otot dapat memendek dan memanjang untuk menciptakan gerakan. Otot melakukan gerakan kontraksi dan relaksasi.

Accelerometer adalah sensor yang berfungsi untuk mengukur percepatan linear yang disebabkan oleh gerak benda atau percepatan gravitasi bumi. Accelerometer digunakan untuk mengukur percepatan gravitasi bumi (inklinasi), mendeteksi dan mengukur getaran Sensor accelerometer mengukur percepatan akibat gerakan benda yang melekat padanya. ADXL345 adalah piranti kecil dengan konsumsi daya rendah yang memiliki 3 sumbu untuk mengukur percepatan dengan resolusi tinggi (13-bit). Piranti ini dapat diakses menggunakan komunikasi SPI atau $\mathrm{I}^{2} \mathrm{C}$.

Jaringan Syaraf Tiruan (JST) merupakan paradigma pengolahan informasi yang terinspirasi oleh sistem syaraf secara biologis seperti proses informasi pada otak manusia[4]. Jaringan syaraf tiruan mempunyai kemampuan untuk memprediksi data keluaran berdasarkan data masukkan yang diberikan. Kemampuan memprediksi didapatkan dengan cara proses pelatihan pada jaringan yang dibuat. 


\section{Metode Penelitian}

\subsection{Electromyograf}

Pada penelitian ini otot wajah yang akan digunakan adalah otot frontalis, yaitu otot yang halus dan lentur yang berada di bagian dahi. Otot ini termasuk dalam otot lurik dimana otot ini digerakkan secara sadar dan dapat bergerak keatas atau kebawah. Sensor EMG diletakkan pada sisi dominan penggunanya, jika pengguna kursi roda lebih dominan memakai tubuh bagian kanan maka sensor diletakkan pada dahi sebelah kanan, sedangkan jika pengguna kursi roda lebih dominan memakai tubuh bagian kiri maka sensor diletakkan pada dahi bagian kiri.

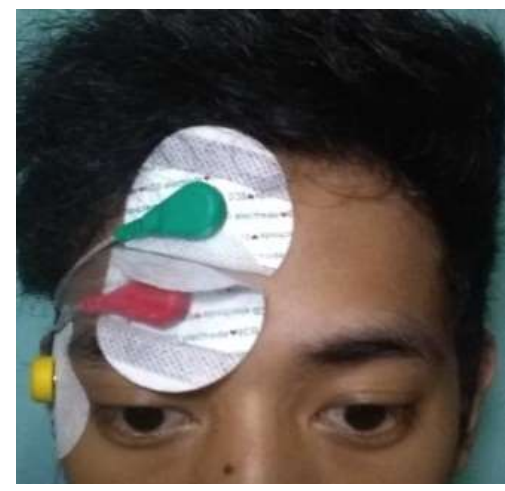

(a)

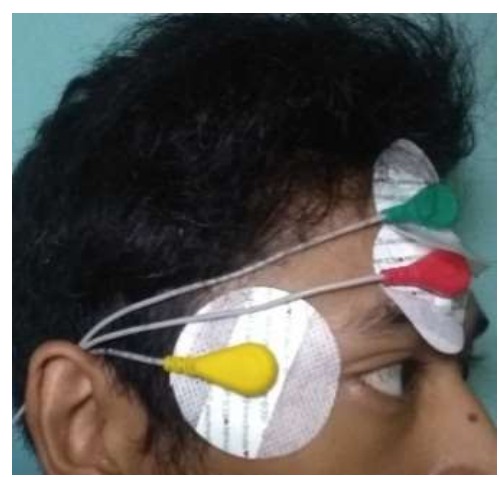

(b)

Gambar 1 - (a) Pemasangan elektroda tampak depan (b) Pemasangan elektroda tampak samping

Electromyograph (EMG) merupakan peralatan yang digunakan untuk mengukur dan mengevaluasi potensial listrik ekstraseluler yang dihasilkan oleh otot. Sinyal electromyogram (EMG) adalah hasil representatif dari potensial listrik yang dihasilkan oleh depolarisasi membran luar serat otot. Serat otot yang aktif selama kontraksi akan menghasilkan aktivitas elektrik dan menghasilkan sinyal electromyogram (EMG).

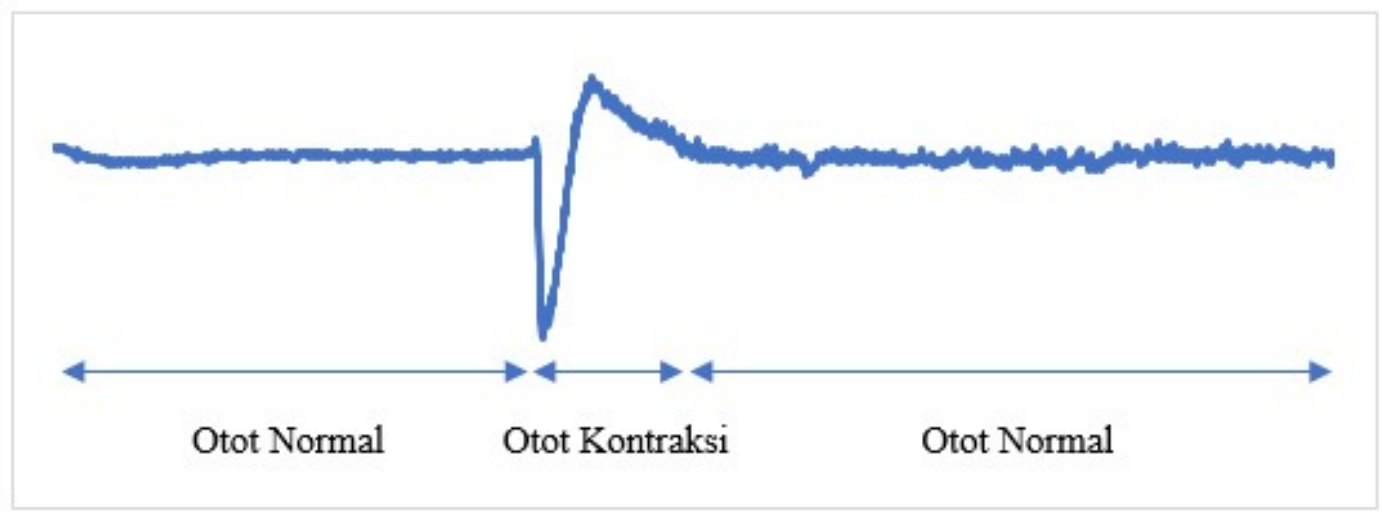

Gambar 2 Sinyal Electromyogram(EMG).

\subsection{Sensor Accelerometer}

Pada penelitian ini kondisi pergerakan model kursi roda yang diinginkan adalah 5 kondisi yaitu kondisi berhenti, maju, mundur, belok kanan, dan belok kiri. Pada tabel 1 dapat dilihat hasil dari pembacaan nilai $\mathrm{x}$, y dan z pada tiap-tiap kondisi dengan sensor accelerometer. 
Tabel 1 Nilai X, Y dan Z Pada Pengujian Sensor Accelerometer

\begin{tabular}{llll}
\hline Kondisi & Axis X & Axis $\mathbf{Y}$ & Axis Z \\
\hline \multirow{3}{*}{ Normal } & -2 & -137 & 186 \\
& -3 & -135 & 185 \\
& -4 & -136 & 186 \\
\hline \multirow{3}{*}{ Maju } & 3 & -237 & 78 \\
& 5 & -236 & 78 \\
& 5 & -234 & 79 \\
\hline \multirow{3}{*}{ Mundur } & 2 & -57 & 217 \\
& 3 & -57 & 217 \\
& 4 & -56 & 217 \\
\hline \multirow{3}{*}{ Kanan } & -84 & -169 & 142 \\
& -84 & -170 & 142 \\
& -85 & -172 & 141 \\
\hline \multirow{2}{*}{ Kiri } & 115 & -160 & 144 \\
& 106 & -163 & 141 \\
& 101 & -171 & 141 \\
\hline
\end{tabular}

\subsection{Jaringan Saraf Tiruan}

Backpropagation adalah salah satu model JST yang mampu mengenali pola dalam proses pelatihan dan mampu memberikan respon yang benar kepada pola yang hampir sama dengan pola pelatihan dengan baik. Backpropagation juga dapat digunakan untuk mencari nilai prediksi seperti yang akan digunakan pada penelitian ini. Kita dapat mencari nilai data yang akan muncul berdasarkan nilai data sebelumnya. Backpropagation memiliki beberapa unit neuron yang terdapat pada layar tersembunyi. Contoh dari arsitektur backpropagation dengan ditambah bias seperti pada gambar 3 .

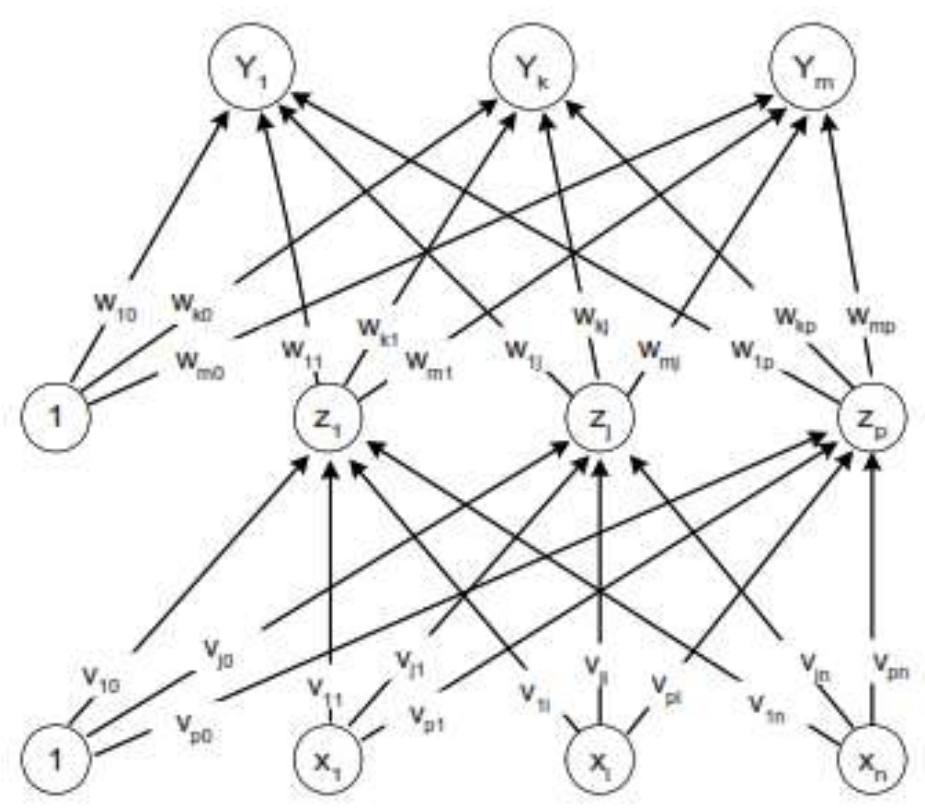

Gambar 3 Arsitektur backpropagation 
Pada Backpropagation fungsi aktivasi diharuskan memenuhi beberapa syarat yaitu : terdeferensial dengan mudah, kontinyu dan fungsi yang tidak turun. Fungsi yang dapat dipakai ada tiga dengan persamaan sebagai berikut :

Fungsi sigmoid :

$$
\begin{gathered}
f(x)=\frac{1}{1+e^{-x}} \\
f^{\prime}(x)=f(x)(1-f(x))
\end{gathered}
$$

Fungsi tansig :

$$
\begin{gathered}
f(x)=\frac{2}{1+e^{-x}}-1 \\
f^{\prime}(x)=\frac{(1+f(x))(1-f(x))}{2}
\end{gathered}
$$

Fungsi purelin :

$$
f(x)=x
$$

Algoritma Pelatihan JST Backpropagation

a. Inisialisasi bobot (bobot awal dengan nilai acak yang kecil)

b. Kerjakan langkah berikutnya selama kondisi berhenti pada nilai false

1. Untuk tiap pasangan elemen yang akan dilakukan pembelajaran, kerjakan :

Feedforward:

a. Tiap-tiap unit input $\left(X_{i}, i=1,2,3, \ldots, \mathrm{n}\right)$ menerima sinyal $x_{i}$ dan meneruskan sinyal ke semua unit pada lapisan tersembunyi.

b. Tiap-tiap unit tersembunyi $(\mathrm{Zj}, \mathrm{j}=1,2,3, \ldots, \mathrm{p})$ menjumlahkan semua sinyal input terbobot :

$$
Z_{-} i n_{j}=V o_{k}+\sum_{i=1}^{n} X_{i} V_{i j}
$$

Output dihitung dengan menggunakan fungsi aktivasi : $\mathrm{Zj}=\mathrm{f}\left(\mathrm{Z} \_\right.$in $)$, kirim sinyal tersebut ke semua unit pada lapisan output.

c. Tiap-tiap unit output $\left(Y_{k}, k=1,2,3, \ldots, \mathrm{m}\right)$ menjumlahkan semua sinyal input terbobot.

$$
Y \_i n k=W o k+i=1 p Z i W j k
$$

Output dihitung menggunakan fungsi aktivasi : $Y_{k}=f(Y$ in). Backpropagation

d. Semua unit input $(\mathrm{Yk}, \mathrm{k}=1,2,3, \ldots, \mathrm{m})$ menerima target pola yang berhubungan dengan pola input pembelajaran, hitung nilai errornya :

$$
\delta_{k}=\left(t_{k}-y_{k}\right) f\left(y_{-i n_{k}}\right)
$$

Hitung koreksi bobot (digunakan untuk memperbaiki nilai $W_{j k}$ ). Hitung juga koreksi bias (digunakna untuk memperbaiki nilai $W o_{k}$ ) :

$$
\Delta W_{o k}=\alpha \delta_{k}
$$

e. Semua unit tersembunyi $\left(Z_{j}, j=1,2,3, \ldots, \mathrm{p}\right)$ menjumlahan delta inputnya (dari unit-unit yang berada pada lapisan diatasnya) : 


$$
\delta_{\_} i n_{j}=\sum_{k=1}^{m} \delta_{k} W_{j k}
$$

Kalikan hasil dengan turunan fungsi aktivasi untuk menghitung informasi error:

$$
\delta_{j}=\delta_{-} i n_{j} f\left(z_{i n_{j}}\right)
$$

Hitung koreksi bobot (untuk memperbaiki nilai $V_{i j}$ ):

$$
\Delta V_{j k}=\alpha \delta_{j} X_{i}
$$

Hitung koreksi bias (untuk memperbaiki nilai $V_{o j}$ ):

$$
\Delta V_{o j}=\alpha \delta_{j}
$$

f. Semua unit output $\left(Y_{k}, k=1,2,3, \ldots, \mathrm{m}\right)$ memperbaiki bias dan bobotnya $(i=1,2,3, \ldots, \mathrm{p})$ :

$$
W_{j k}(\text { baru })=W_{j k}(\operatorname{lama})+\Delta W_{j k}
$$

Semua unit tersembunyi $\left(Z_{j}, j=1,2,3, \ldots, \mathrm{p}\right)$ memperbaiki bias dan bobotnya $(i=1,2,3, \ldots, \mathrm{n})$ :

$$
V_{j k}(\text { baru })=V_{j k}(\operatorname{lama})+\Delta V_{j k}
$$

2. Tes kondisi true atau false.

3. Langkah-langkah diatas adalah untuk pelatihan satu kali siklus (satu epoch). Proses pelatihan diulang sampai target error tercapai atau epoch yang diinginkan terpenuhi.

4. Hasil akhir pelatihan adalah bobot-bobot yang nantinya disimpan untuk proses pengujian. Data yang digunakan pada pelatihan adalah data sinyal EMG sebanyak 7 buah sinyal kontraksi yang akan dibagi menjadi 5 buah sinyal kontraksi untuk pelatihan dan 2 buah sinyal kontraksi untuk pengujian. Dalam penelitian ini, nilai satu sinyal kontraksi terdiri atas sinyal otot normal - sinyal otot kontraksi - sinyal otot normal yang berkesinambungan seperti pada Gambar 2. Data sinyal kontraksi untuk pelatihan dapat dilihat pada Gambar 4, sedangkan Gambar 5 memperlihatkan data sinyal kontraksi untuk pengujian.

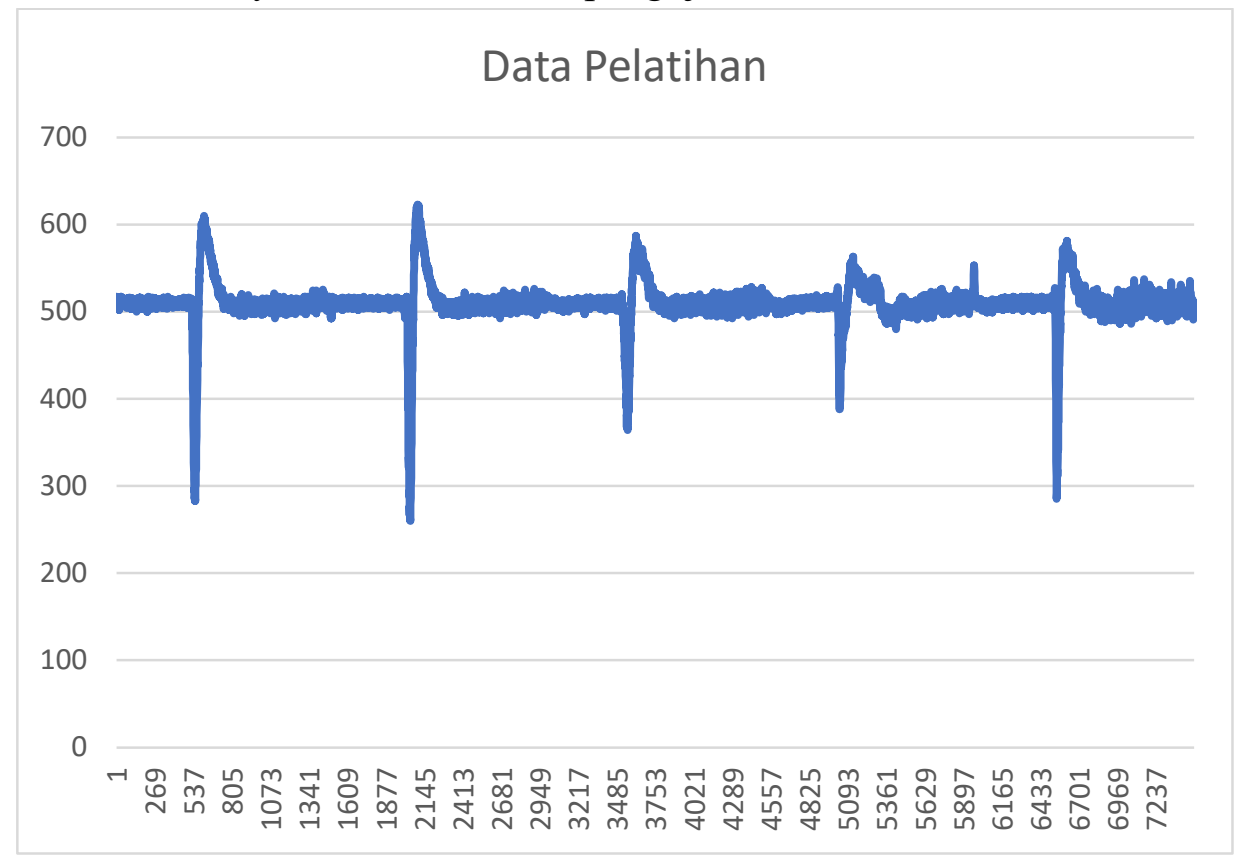

Gambar 3 Bentuk Sinyal Data Pelatihan 


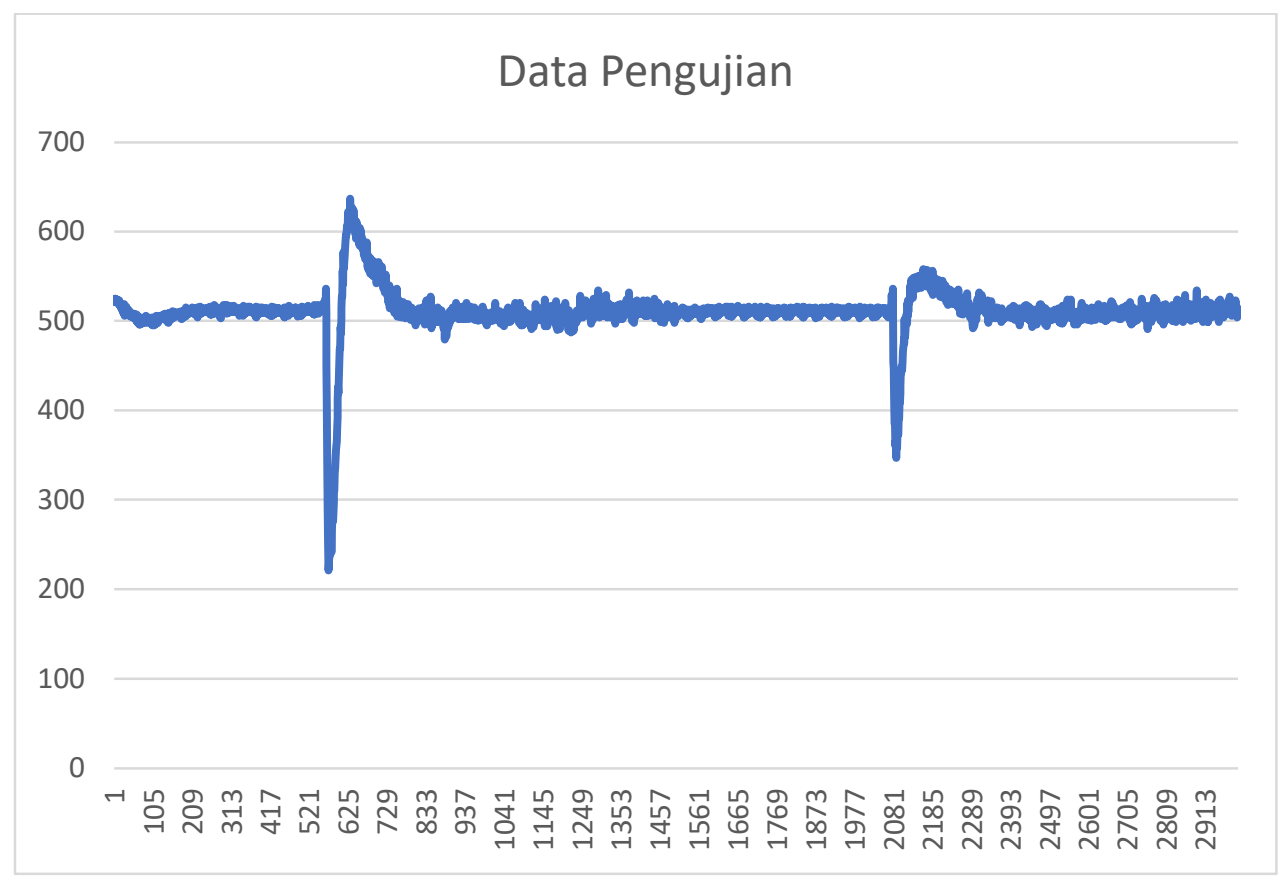

Gambar 4 Bentuk Sinyal Data Pengujian

Untuk proses pelatihan memerlukan 2 buah kumpulan data, yaitu data latih dan data target. Jaringan saraf tiruan pada penelitian ini akan gunakan untuk memprediksi nilai data berikutnya (misal data $\mathrm{x}$ ) dari data sebelumnya (misal data $\mathrm{x}-1$ ). Oleh karena itu perlu adanya pengolahan data untuk mendapatkan data target dari data pelatihan yang sudah kita dapatkan sebelumnya. Proses ini dapat dilakukan dengan aplikasi pengolah angka atau langsung kita terapkan pada program pada matlab. Pola data dapat dapat dilihat seperti pada Tabel 2 berikut.

\begin{tabular}{|c|c|c|}
\hline Pola & Data Latih & Data Target \\
\hline 1 & Data ke-1 & Data ke-2 \\
\hline 2 & Data ke-2 & Data ke-3 \\
\hline 3 & Data ke-3 & Data ke-4 \\
\hline ... & & \\
\hline
\end{tabular}

\subsection{Sistem Model Kursi Roda}

Gambar 5 adalah diagram blok dari penelitian ini secara keseluruhan dimana terdapat 2 buah input dan 1 buah output. Gambar 6 merupakan algoritma dari program Arduino pada penelitian ini. 


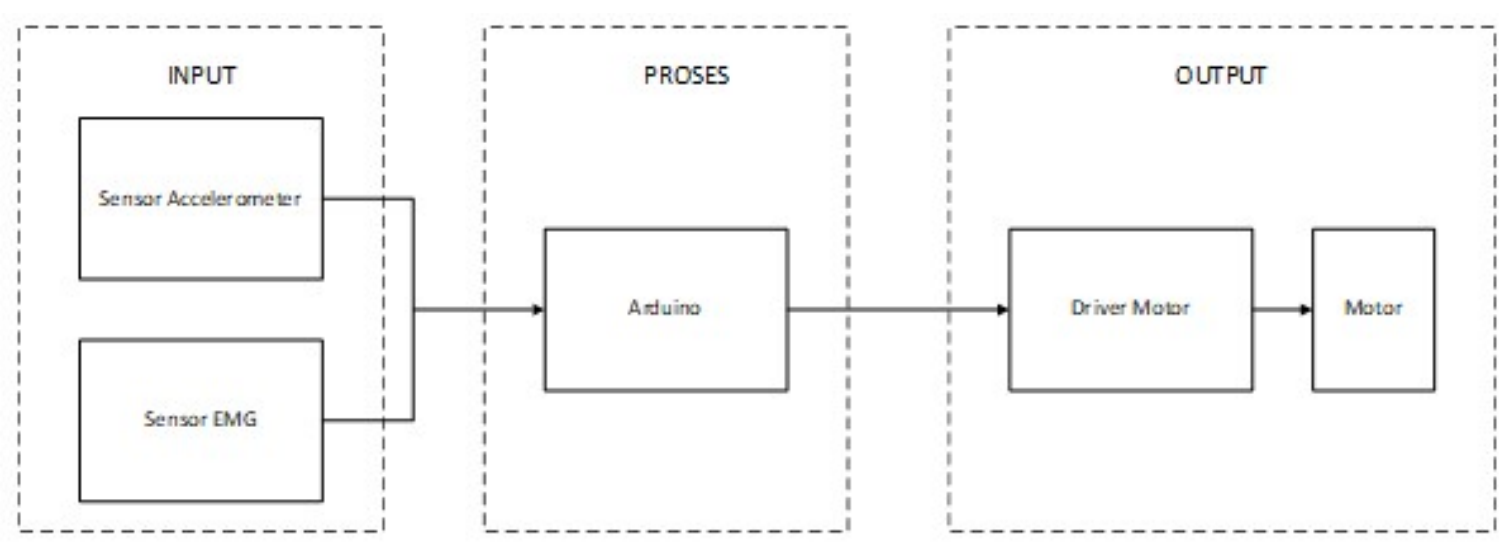

Gambar 5 Diagram Blok Sistem

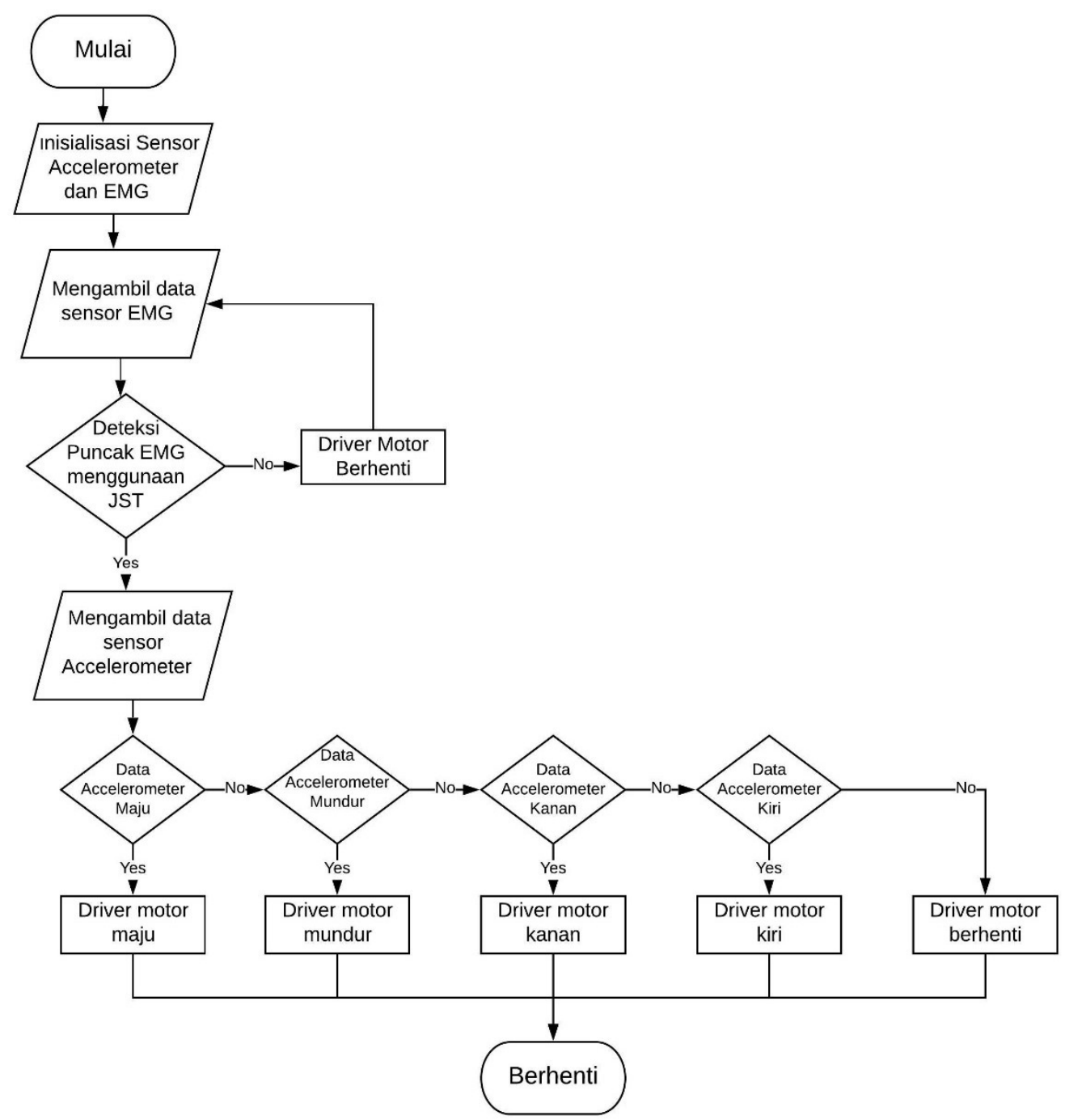

Gambar 6 Algoritma Sistem 


\section{Hasil dan Pembahasan}

Pengujian pada penelitian ini dilakukan untuk memberikan informasi dari sistem yang telah dirancang agar dapat dilihat sejauh mana keberhasilan dari sistem dan memberikan gambaran untuk mempermudah pengembangan. Pada penelitian ini akan ada dua pengujian yaitu pengujian JST yang telah dirancang dan pengujian pergerakan model kursi roda. Sebelum melakukan pengujian keseluruhan, dilakukan pengujian arsitektur JST terlebih dahulu untuk mengetahui arsitektur yang dapat digunakan pada penelitian ini.

Tabel 3 Hasil Pengujian Arsitektur Jaringan Syaraf Tiruan

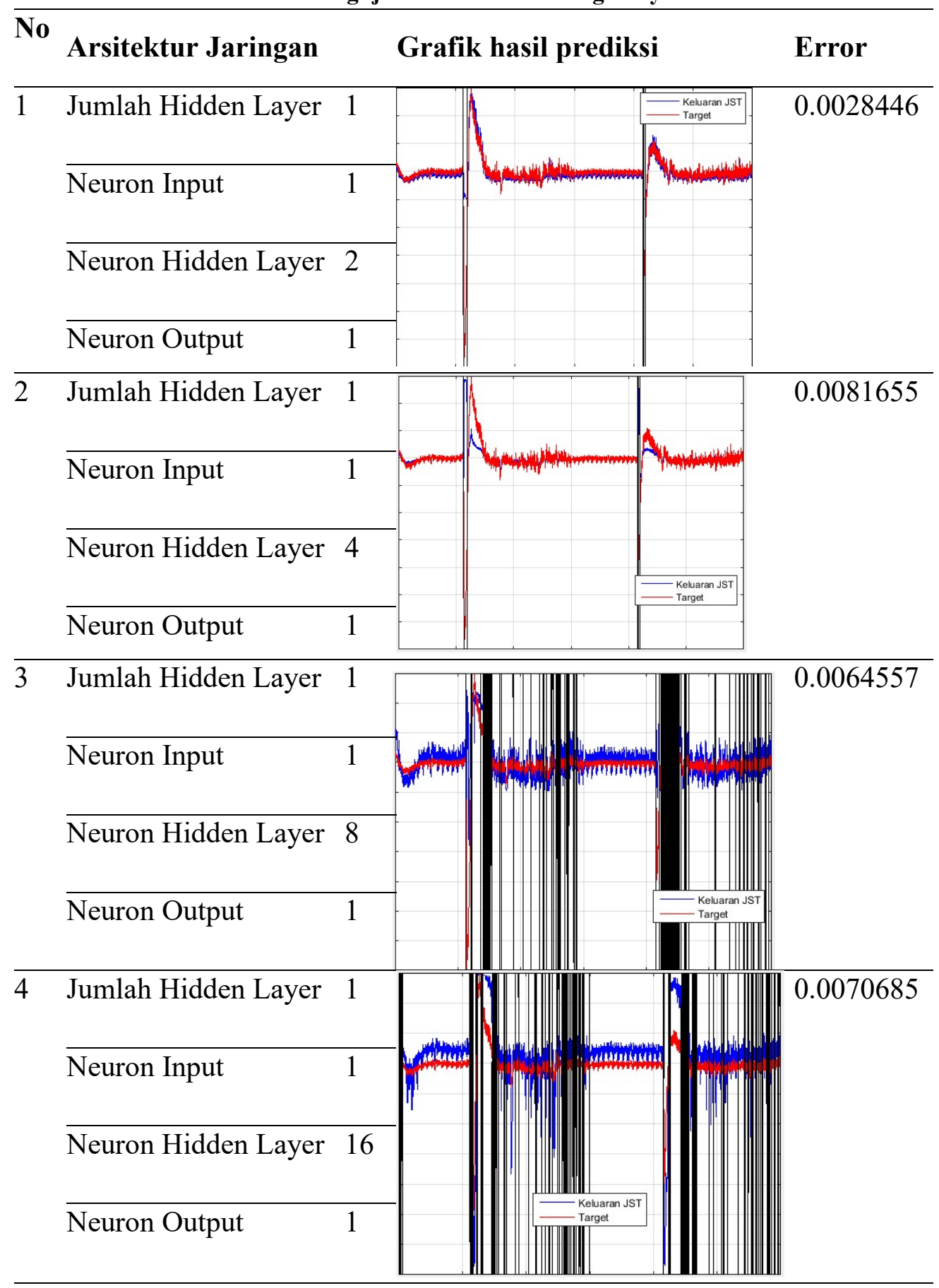




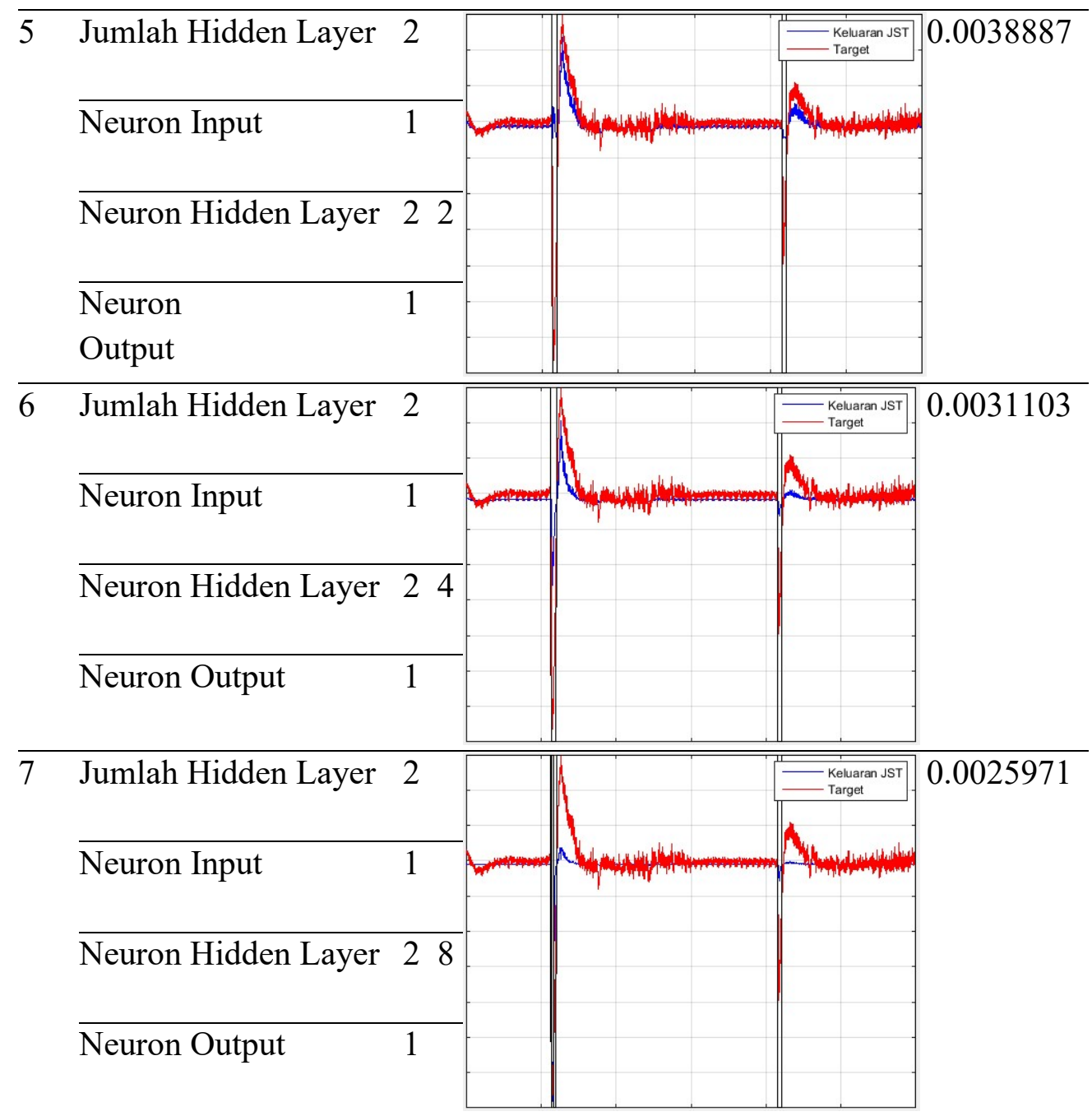

Dari Tabel 3 dapat dilihat hasil error dan grafik hasil pelatihan. Dari grafik tersebut dapat dilihat hasil prediksi dari jaringan syaraf tiruan dan sinyal puncak yang terdeteksi. Garis hitam pada grafik menunjukkan puncak yang terdeteksi yang digunakan untuk menunjukkan adanya kontraksi. Berdasarkan Tabel 3 dengan 1 buah layar tersembunyi dan arsitektur 121 , jaringan sudah dapat mendeteksi adanya kontraksi yang ditandai dengan adanya garis hitam dan mendapatkan error prediksi sebesar 0.0028446. Namun dengan ditambahnya neuron pada layar tersembunyi, yang terjadi adalah sinyal hasil prediksi semakin memiliki error yang besar sehingga kontraksi pun sulit dideteksi. Dengan arsitektur menggunakan 2 buah layar tersembunyi didapatkan hasil error yang baik dan mampu mendeteksi kontraksi dengan baik, tetapi bentuk sinyal yang dihasilkan dari prediksi tidak lebih baik dari jaringan dengan arsitektur 12 1. Dari pembahasan di atas dapat disimpulkan bahwa jaringan dengan arsitektur 121 adalah yang terbaik dan bisa digunakan dalam penelitian ini. Bentuk arsitektur yang digunakan menggunakan arsitektur seperti pada Gambar 7. 


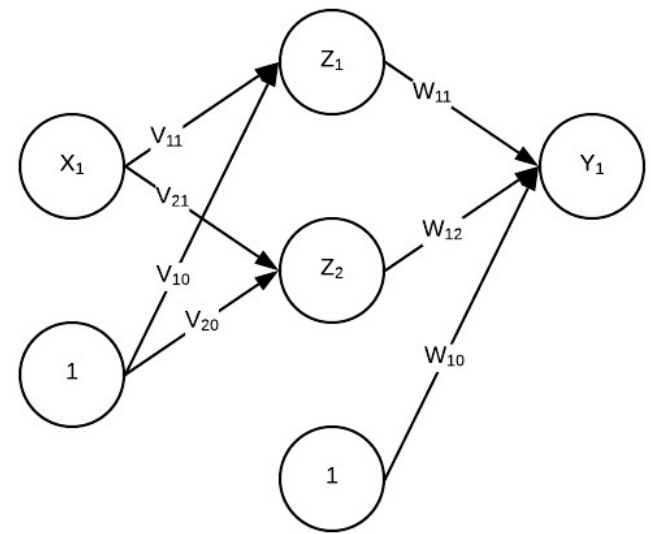

Gambar 7 Arsitektur Jaringan Sistem

Setelah pembuatan JST telah selesai, dilakukan pengujian pada model kursi roda yang telah dibuat. Pada Gambar 8 adalah pemasangan accelerometer pada kepala, sedangkan pemasangan sensor EMG dapat dilihat pada Gambar 1. Gambar 9 adalah pengujian langsung pada model dengan menggunakan Arduino untuk menghasilkan pergerakan pada model sesuai perintah yang dihasilkan dari kepala.

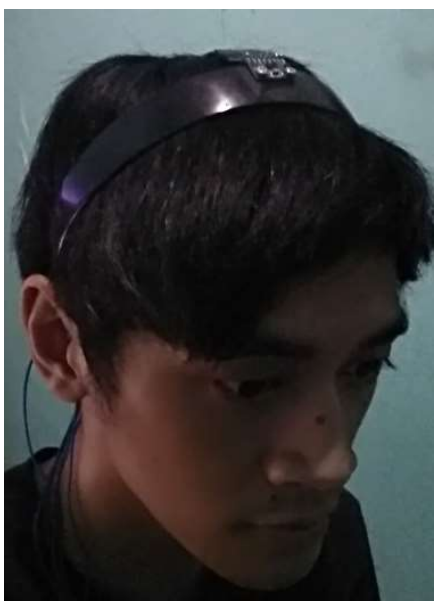

(a)

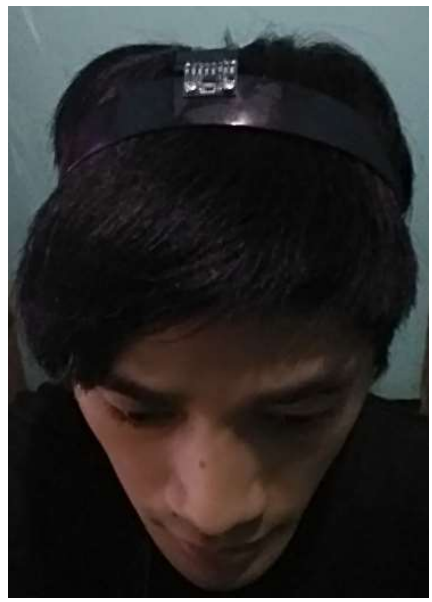

(b)

Gambar 8 - (a) Pemasangan sensor accelerometer tampak samping (b) Pemasangan sensor accelerometer tampak depan

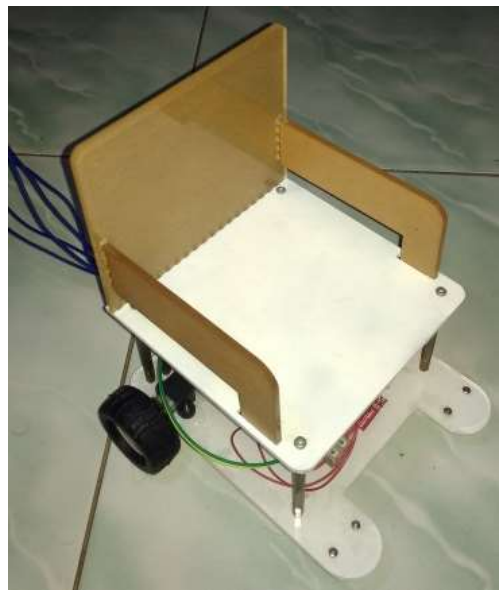

Gambar 9 Pengujian pada model 
Pada pengujian JST pada Arduino, dilakukan pengujian untuk mendapatkan hasil berupa terdeteksinya keadaan saat otot berkontraksi. Setelah dilakukan proses training pada JST dan didapatkan bobot yang sesuai maka bobot tersebut yang akan dipakai pada pengujian. Pada Gambar 10 menunjukkan dua buah data yaitu sinyal yang dihasilkan oleh sensor EMG yang ditunjukkan dengan garis warna biru, dan kontraksi terdeteksi yang ditunjukkan oleh warna oranye. Kontraksi terdeteksi saat hasil nilai keluaran dari JST dari sinyal EMG saat ini (x) lebih besar dari nilai sensor EMG sebelumnya (x-1). Dalam tingkatan ini dapat dikatakan bahwa proses pendeteksian kontraksi menggunakan jaringan syaraf tiruan dinyatakan berhasil.

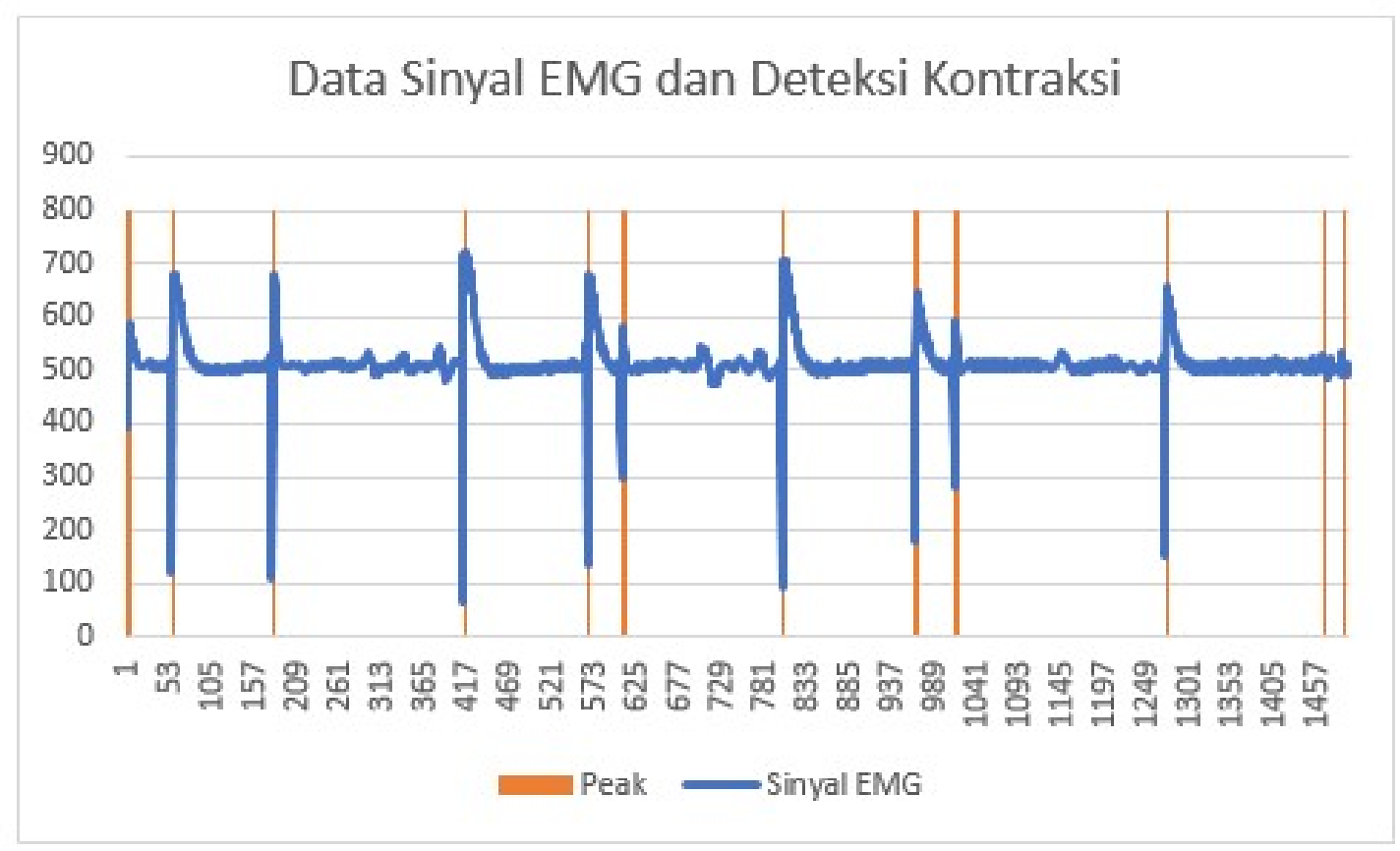

Gambar 10 Hasil Pembacaan Sinyal EMG dan Deteksi Kontraksi

Dari nilai x, y, z yang didapatkan dari sensor accelerometer berdasarkan tiap-tiap kondisi maka selanjutnya dapat diaplikasikan pada percabangan untuk menentukan arah pergerakan dari model kursi roda. Pada Gambar 11 adalah hasil pergerakan model kursi roda setelah digabungkan dengan pengaktifan sensor accelerometer berdasarkan pembacaan kontraksi otot dari sensor EMG. Area berwarna oranye adalah keadaan saat sensor accelerometer aktif sedangkan warna biru menunjukan kondisi pergerakan kursi roda. Nilai 0 sampai 4 pada warna biru merepresentasikan kondisi pergerakan kursi roda. Nilai 0 menandakan kondisi kursi roda berhenti, nilai 1 kondisi kursi roda bergerak maju, nilai 2 menandakan kondisi kursi roda bergerak mundur, nilai 3 menandakan kondisi kursi roda berbelok ke kanan sedangkan nilai 4 menandakan kondisi kursi roda berbelok ke kiri. Dari Gambar 11 dapat dilihat pada saat sensor accelerometer dalam keadaan mati maka nilai pada garis biru bernilai 0 atau kursi roda dalam keadaan berhenti. 


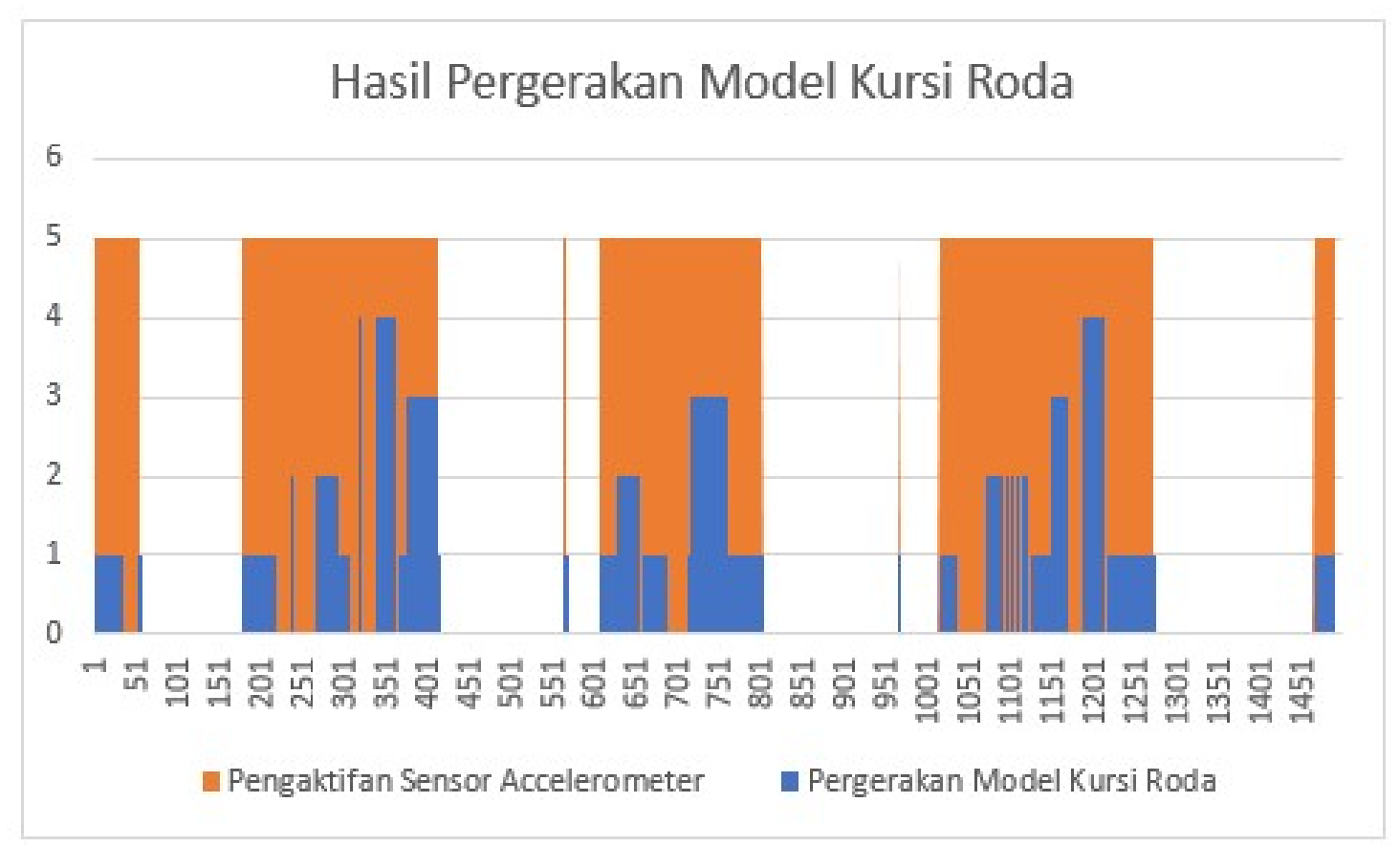

Gambar 9 Hasil Pergerakan Model Kursi Roda

\section{Gambar}

Dari hasil yang didapatkan pada penelitian ini, pemanfaatan jaringan saraf tiruan dan sensor accelerometer pada kendali model kursi roda merupakan sesuatu hal yang dapat diaplikasikan untuk kendali kursi roda elektrik. Namun, tentu saja masih banyak dari sistem pada penelitian ini yang perlu dikembangkan lagi, mengingat penggunaan kursi roda bagi pasien penyandang disabilitas pada kaki adalah sebuah kebutuhan yang akan sangat membantu pasien dalam menjalankan kegiatan sehari-hari.

\section{Daftar Pustaka}

A. Pradana, F. Hidayat, M. A. Taksiono, M. F. Winarto, L. Y. K. Hatta, "Rancang Bangun Electricwheelchair Controlled by Android Device with Speech Recognition Command Fuction", in Pekan Ilmiah Mahasiswa Nasional Program Kreativitas Mahasiswa - Karsa Cipta 2013, (2013)

J. G. Sinataya, Tasripan, and A. Arifin, "Pengolahan Sinyal EMG Sebagai Perintah Kontrol Untuk Kursi Roda Elektrik” in JURNAL TEKNIK ITS Vol. 7, No. 2, (2018).

A. Y. Ruzalianto, Analisa Sinyal Otot Pergelangan Tangan Dalam Kondisi Flexi dan Dalam Kondisi Extensi" in Thesis Universitas Airlangga, (2016).

T. Sutojo, E. Mulyanto, V. Suhartono, "Kecerdasan Buatan", Penerbit ANDI, 2011.

Sinichi Aso, "Diving Electric Car by Using EMG Interface", (2006).

F. H. Tyastuti, "Pengendalian Kursi Roda Elektrik Menggunakan Sinyal Electromyogrsphy dengan Metode Transformasi Fourier Khusus", 2017. 
Y. A. Lesnussa, S. Latuconsina, E. R. Persulessy, "Aplikasi Jaringan Syaraf Tiruan Backpropagation untuk Memprediksi Prestasi Siswa SMA(Studi kasus: Prediksi Prestasi Siswa SMAN 4 Ambon)", in Jurnal Matematika Integratif Volume 11 No 2, (2015).

Ilham A. E. Zaeni, Aji P. Wibawa, Aripriharta, Siti Sendari, "Implementation of Fuzzy Decision to Control Patient Room Facilities using Eye Blink", in IOP Conference Series: Materials Science and Engineering, Volume 336, The 2nd International Conference on Vocational Education and Electrical Engineering (ICVEE), (2017)

A. Ferreira, R. L. Silva, W. C. Celeste, T. F. Bastos Filho, M. Sarcinelli Filho, "Humanmachine interface based on muscular and brain signals applied to a robotic wheelchair", in Journal of Physics: Conference Series, Volume 90, 16TH ARGENTINE BIOENGINEERING CONGRESS (SABI 2007) AND THE 5TH CONFERENCE OF CLINICAL ENGINEERING, (2007)

E. P. G. Rakasena, L. Herdiman, "Electric wheelchair with forward-reverse control using electromyography (EMG) control of arm muscle", in Journal of Physics: Conference Series, Volume 1450, International Conference on Applied Science and Technology (iCAST on Engineering Science), (2019)

Kyuwan Choi, M. Sato and Y. Koike, "A new, human-centered wheelchair system controlled by the EMG signal," The 2006 IEEE International Joint Conference on Neural Network Proceedings, Vancouver, BC, (2006)

R. Mahendran, "EMG signal based control of an intelligent wheelchair," 2014 International Conference on Communication and Signal Processing, Melmaruvathur, (2014)

L. Wei, H. Hu and K. Yuan, "Use of forehead bio-signals for controlling an Intelligent Wheelchair," 2008 IEEE International Conference on Robotics and Biomimetics, Bangkok, (2009)

Firoozabadi, S. Mohammad P., M. Asghari Oskoei, and Huosheng Hu. "A human-computer interface based on forehead multi-channel bio-signals to control a virtual wheelchair." Proceedings of the 14th Iranian conference on biomedical engineering (ICBME). 2008.

R. Hardiansyah, A. Ainurrohmah, Y. Aniroh and F. H. Tyas, "The electric wheelchair control using electromyography sensor of arm muscle," 2016 International Conference on Information \& Communication Technology and Systems (ICTS), Surabaya, (2016) 